\title{
ISABEL DE VILLENA I FAMÍLIA: UNA RECONSIDERACIÓ BIOGRÀFICA
}

\section{ISABEL DE VILLENA AND HER FAMILY: A BIOGRAPHICAL REAPPRAISAL}

\author{
ROSANNA CANTAVELLA \\ Universitat de València \\ Clare Hall, University of Cambridge
}

Resum: Aquest article pretèn sistematitzar les notícies historiogràfiques de les últimes dècades en allò que pot ser aplicat a augmentar el nostre coneixement de la vida d'Isabel de Villena. En primer lloc es mostra que, lluny de ser una orfeneta desvalguda, la filla d'Enric de Villena comptava amb una significativa xarxa d'oncles, ties i cosins, i aquesta ajuda a entendre l'opció de l'autora pel franciscanisme. En la segona part s'analitzen les autèntiques raons de per què Isabel de Villena, que comptava amb una considerable fortuna, va ser integrada a la cort de la reina Maria a la mort del seu pare, que havia estat desterrat pels Trastàmares: com a filla de l'últim descendent masculí legítim d'un dels aspirants al tron d'Aragó a la mort de Martí l'Humà, el seu futur havia de ser supervisat amb compte.

Paraules clau: Isabel de Villena; Enric de Villena; Alfons el Vell; Casa de Barcelona; dinastia Trastàmara; Regne de València.

\begin{abstract}
This article aims to systematize the last decades' historiographical contributions on the life of Isabel de Villena. In the first section it is shown that, far from being a helpless orphan, Enric de Villena's daughter could rely on a significant net of uncles, aunts and cousins, which helps understand the author's choice of Franciscanism. The second section analyzes the true reasons why Isabel de Villena, who possessed an important fortune, was brought up in queen Maria's court when her father, who had been exiled by the Trastámara brothers, died: as the daughter of the last legitimate male descendant of one of the claimants of the throne of Aragon in the aftermath of Martí l'Humà's death, her future had to be carefully monitored.
\end{abstract}

Keywords: Isabel de Villena; Enric de Villena; Alfonso I, Duke of Gandia; House of Barcelona; Trastámara dynasty; Kingdom of València.

1. La xarxa familiar.- 2. Motius per a l'adscripció d'Isabel de Villena a la cort.3. Bibliografia citada. 


\section{LA XARXA FAMILIAR}

Aquest article té per objecte actualitzar notícies biogràfiques de l'escriptora Isabel de Villena (1430-90), especialment pel que fa a les seues vinculacions familiars ${ }^{1}$. Nascuda Elionor ("de Villena" per reivindicació familiar, però "d'Aragó" per nissaga), la seua condició de filla il·legítima és incontestable, ja que a l'hora de prendre possessió com a abadessa va necessitar la dispensa papal de defectu natalium per aquest motiu ${ }^{2}$. Fa temps que va quedar descartada la seua vinculació a la casa castellana dels Manuel de Villena ${ }^{3}$. Segueix essent un enigma qui va ser la seua mare; i no fa gaire fins es va arribar a dubtar de qui en fos el pare: Dominique de Courcelles va atribuir a Pedro Cátedra el suggeriment de la paternitat no d'Enric de Villena, sinó del seu germà petit Alfons ${ }^{4}$. No se sap gaire d'aquest Alfons; però sí que se sap que va morir molt jove, al voltant de l'any $1400^{5}$, és a dir uns trenta anys abans del naixement d'Isabel; de manera que és impossible aquella hipòtesi. Però tenia Enric de Villena més germans?

${ }^{1}$ El nucli del present treball va ser presentat com a part de la meua lliçó de càtedra, a l'octubre de 2010. He de donar gràcies pel seu assessorament a Mateu Rodrigo Lizondo i Jaume Chiner, sempre generosos amb els seus amplis coneixements.

Abreviatures utilitzades: ARV = Arxiu del Regne de València; AHN = Archivo Histórico Nacional; CODOIN = Colección de documentos inéditos para la historia de España .

${ }^{2}$ López 1943, p. 511.

${ }^{3} \mathrm{Fa}$ un breu resum d'aquesta impossibilitat genealògica Orts 2011, pp. 9-11, i conclou: "És un gran error anomenar-la Elionor Manuel de Villena -com apareix esmentada en alguns llocs-, quan ella era, en realitat, Elionor d'Aragó i de Castella, descendent dels reis lleonesos, castellans i aragonesos-navarresos fins els temps de l'inici de les conquestes dels territoris musulmans hispànics $i$, per agnació rigorosa, dels comtes catalans fins a l'època carolíngia" (ibidem, p. 11). Jo mateixa he resseguit el procés de la confusió: va començar, almenys, al segle XVII amb Melcior de Villena, destacat membre de la branca dels Manuel de Villena instal-lada a València al segle XV. Vegeu l'elogi fúnebre que dedica al Doctor de Villena Joan Baptista Ballester (AA.DD. 1655): "Y assí nuestro insigne difunto fue destello del calificado esplendor, y bástago de la ilustre cepa de los antiguos Villenas de Castilla, señores de Villena, y de Escalona, aviendo usado en esta Ciudad, él y los suyos por más de duzientos años las armas de los Villenas señores de Villena (que son un braço alado empuñada la espada) como consta del antiquíssimo libro de la vida de Christo, que en idioma [iii r.] Valenciano escrivió Soror Isabel de Villena, donde van estampadas por suyas las dichas armas, y calificada su sangre nobilíssima (...) la qual escrivió en idioma valenciano un libro de la vida de Christo (que, en la prosapia de los Villenas, hasta las mujeres son sabias)" [xvii v.]. Podria pertànyer als Manuel de Villena la família de Ferrando de Manuel, "forastés" d'Oriola que figuren al llibre d'almoines de la Trinitat? Vegeu Mata 1991, entrades 4404 a 4408.

${ }^{4}$ Courcelles 2000, p. 105. De Courcelles remetia el suggeriment erròniament a la introducció de Pedro Cátedra a la seua edició de les obres de d'Enric de Villena (sense indicació de volum ni de pàgina); però Cátedra (1994) no esmenta la qüestió en cap de les introduccions als respectius volums d'aquesta publicació. Vaig preguntar a l'autor sobre la qüestió quan ens vam veure al congrés de la SEMYR a Oviedo, en 2010, i aquest va contestar que no tenia memòria d'haver tractat el tema; només recordava haver-se preguntat, en algun altre lloc, quin dels dos germans, Enric o Alfons, hauria estat el major.

${ }^{5}$ L'última notícia que se'n coneix és la seua intervenció en la cerimònia de nomenament d'Alfons el Vell com a duc de Gandia, en 1399 (Castillo 1999, pp. 290 i 283). 
Doncs sí, en tenia dos més: l'illlegítim Galvany de Villena, i una germana legítima que s'hauria dit també Elionor de Villena, igual que la neboda escriptora, i igual que una tia àvia. Aquesta Elionor de Villena germana d'Enric, es va casar el 1414, segons Zurita, amb Antoni de Cardona ${ }^{6}$, germà del Joan Ramon Folch de Cardona amb qui s'havia casat sa tia Joana d'Aragó (vegeu infra); diversos historiadors recents confirmen Elionor com a germana d'Enric i de Galvany ${ }^{7}$. Elionor va morir molt abans del naixement de l'escriptora en 1430, ja que el seu marit Antoni de Cardona s'hauria casat en segones noces el $1421^{8}$. La seua mort prematura ens convida a especular si Enric vaja donar a la seua filla aquest nom en record de la germana difunta -o si bé, simplement, volia mantenir la molt arrelada tradició de l'antropònim en la família. Elionor és nom de reina hispànica (l'última en Aragó, l'esposa de Martí l'Humà); com també Isabel, nom de la reina santa de la casa de Barcelona9. És important també referir-nos a dues altres ties àvies de l'escriptora, germanes de Pere de Villena i de la Joana d'Aragó adés esmentada: Elionor i Violant d'Aragó. El que sabem de la vida d'Elionor és trist: es va casar amb un cosí germà, Jaume de Prades, i va quedar viuda jove (amb almenys una filla, com veurem més avall), i vivia d'un estipendi anual, establert com a compensació per l'altíssim dot que se li devia, ja que el pare no l'havia pogut pagar. Tanmateix, una vegada mort el pare, el germà Alfons el Jove no sols li va retirar el pagament, sinó que la mantenia presonera acusant-la de deshonestat. Més endavant, Elionor va ingressar en el convent de les menoretes (clarisses) de Santa Isabel i Santa Clara de València, del qual era abadessa la seua germana Violant ${ }^{10}$.

Pel que fa a Violant, aquesta va ingressar a les clarisses de Xàtiva el 1403, i el 1405 va ser traslladada, com a abadessa, a l'esmentat convent de menoretes de Santa Isabel i Santa Clara de València, després conegut com de la Puritat ${ }^{11}$. Violant va promoure la fundació d'una efímera primera comunitat de clarisses a Gandia, per a la qual va destinar 3.000 sous. El procés fundacional va durar més de cinc anys, i les primeres clarisses van arribar a Gandia el 1429, un any abans del naixement d'Isabel de Villena. Però quinze anys després, el convent gandienc va haver de tancar, degut a les consequiències econòmiques derivades dels plets per l'herència de la seua protectora, $\mathrm{i}$

${ }^{6}$ Zurita 1977, vol. V p. 388.

${ }^{7}$ Castillo 1999, pp. 123-124 i García Oliver et al. 2009-2010, vol. I p. 11.

${ }^{8}$ Vegeu Enciclopèdia.cat, s.v. Cardona i de Luna, Antoni de.

9 "En el cas d'Elionor de Villena, segurament aquesta prengué el nom d'Isabel en honor i en memòria de la santa reina de Portugal Isabel d'Aragó, filla dels seus avantpassats els reis Pere III de la Corona d'Aragó (1339-1385) i Constança de Hohenstaufen" (Orts 2011, p. 9).

${ }^{10}$ Castillo 1999, pp. 136-138.

${ }^{11}$ Ibidem, pp. 138 i 51. 
a la desaparició dels membres de la nissaga d'Aragó en el ducat de Gandia ${ }^{12}$. Com és ben sabut, per iniciativa de la reina Maria l'any 1443 començaren els tràmits per a traslladar aquest grup monacal des de Gandia fins a València, a la que seria la nova comunitat clarissa de la Trinitat desplaçant l'antic cenobi de trinitaris. Les clarisses gandienques no van ser reagrupades en l'altre convent de clarisses de València, la Puritat, perquè es regien per la regla reformada de Tordesillas, i per tant pertanyien a una branca més austera que no aquelles altres ${ }^{13}$. És interessant que la comunitat fos impetrada per Violant, que no hi va pertànyer. Amorós ens diu que Violant sols havia acceptat ser abadessa de la Puritat a insistència personal de Martí l'Humà ${ }^{14}$. Aquesta resistència, unida al gest de la fundació gandienca, sembla apuntar a un seu ideal de vida més auster: la comunitat de Gandia hauria representat l'opció de vida religiosa que Violant, per imperatius de política religiosa segons sembla, no havia pogut seguir - però que podria seguir la seua neboda néta, Isabel de Villena.

Tot i que encara se sap poc de Violant d'Aragó, una cosa sí que hem de tenir present: que probablement va arribar a conèixer Isabel de Villena en la primera infantesa d'aquesta, com també potser l'enigmàtica clarissa viuda Elionor d'Aragó, ja que vivien a la mateixa ciutat. Per això convé no perdre de vista, a l'hora de considerar la decisió de la jove d'entrar en religió, i la seua particular advocació franciscana, la possible influència de les ties àvies clarisses, o almenys la del digne i respectat model que la tia abadessa representava.

Centrem-nos ara en Galvany de Villena, l'únic oncle carnal que va conèixer la filla d'Enric. Aquest va ser un ric i notable cavaller, considerat entre els barons més poderosos de la noblesa valenciana, i apareix esmentat en diversos documents exhumats al llarg de les darreres dècades pels historiadors. El benestar econòmic de Galvany es pot apreciar, per exemple, en el testimoni d'una taxació entre els membres del braç militar valencià el 1429-1430 per subvencionar la guerra d'Alfons el Magnànim contra Castella. Aquest text resulta el més semblant a un cens econòmic de la noblesa valenciana: Galvany és un dels més destacats contribuents, aportant-hi 672 sous $^{15}$, cosa que el situa entre el $6 \%$ del braç que contribueix amb el $24 \%$ de l'oferta al rei ${ }^{16}$. L'any 1431 el seu nom apareix entre els dels més destacats nobles de la corona

${ }^{12}$ Ibidem, p. 51; Amorós 1960, pp. 453-458.

${ }^{13}$ Amorós 1960, pp. 457-463.

14 "Habiendo sido elegida abadesa del monasterio de Santa Isabel (hoy de la Puridad) de Valencia, no obstante su repugnancia para este traslado, tuvo que aceptar el cargo bajo el influjo de fuertes presiones, siendo la más poderosa la que le vino de su primo Martin el Humano, rey de Aragón. En el año 1405 ejercía ya el cargo de abadesa en el monasterio de Valencia" (Amorós 1960 , p. 453, n. 16).

${ }^{15}$ López 1991, p. 630.

${ }^{16}$ Ibidem, p. 628; López 2005, p. 85, n. 199. 
d'Aragó, en el compromís per acabar la guerra amb Castella ${ }^{17}$. També figura esmentat entre els consellers del rei Alfons en 1437 (vegeu nota 31).

La seua prosperitat material, tan allunyada de les dificultats que van acompanyar la vida del seu germanastre, el legítim Enric ${ }^{18}$, s'explica per, almenys, la donació en vida que li va fer en 1402 el seu avi, el duc Alfons el Vell, dels castells de Xirell i de Corts de Pallàs, a la vall d'Aiora ${ }^{19}$, en un lloc molt convenient: el pas de Castella al regne de València; possessions que després heretaria la seua filla única Caterina, i d'aquesta n'heretaria les rendes dels molins, com veurem més avall, la pròpia Isabel de Villena en usdefruit.

El 1407, el duc faria una donació similar a un altre nét: Hug de Cardona $^{20}$. Aquest, personatge un poc més conegut ara, era fill de Joana d'Aragó, filla d'Alfons el Vell, a qui aquest va dirigir una obra educativa amb motiu del seu matrimoni ${ }^{21}$. Hug era cosí germà de Galvany i d'Enric, i per tant oncle segon d'Elionor/Isabel. Hi ha notícia de dues altres ties d'Isabel de Villena, també dites Violant i Elionor, que apareixen documentades reclamant els seus drets a una part de les 3.000 lliures amb què l'abadessa Violant d'Aragó havia dotat el convent de Gandia: una és Elionor de Prades, que reclama 2.000 sous de la prebenda de Gandia, al·legant el cobrament de deutes; plet que aquesta Elionor va acabar guanyant a les monges ${ }^{22}$. Per nom, i per cognoms, Elionor de Prades pogué ser filla de l'esmentada germana de Violant, l'Elionor d'Aragó casada amb Jaume de Prades, després enviudada, presonera d'Alfons el Jove, i professa clarissa al convent de la germana abadessa. L'altra reclamant figura també com a neboda de Violant (tot i que Amorós no ens en dóna més dades), i és, igualment, abadessa clarissa, i del convent de Xàtiva, en el qual havia iniciat Violant la seua vida religiosa. També els tribunals van fallar en favor d'aquella neboda ${ }^{23}$. Com que els plets van ser llargs i es van donar a la

${ }^{17}$ Bofarull 1869, p. 100.

${ }^{18}$ Encara està per fer-se una biografia actualitzada d'Enric de Villena, que supere els tòpics antics; d'altra banda, m'és impossible presentar ací una bibliografia exhaustiva sobre aquest. Un breu resum biogràfic, amb atenció especial al calendari de redacció de les seues obres, es pot llegir a l'edició de Cátedra (1994). Abans, el mateix Cátedra (1981,1983) n'havia aportat ja interessants notícies. Vegeu també Cátedra, Carr 2001. La més antiga monografia sobre ell, molt subjectiva, és la de Cotarelo (1896); les observacions personals més antigues, les de Germán Pérez de Guzmán al seu Generaciones y semblanzas (Tate 1965, pp. 188-189).

${ }^{19}$ Castillo 1999, p. 127, i notes 294 i 295. Català i Pérez presenten notícies referides a la gestió per part de Galvany del seu senyoriu (2002, pp. 38-39 i 82-88). L'Enciclopèdia Catalana li atribueix incorrectament d'haver heretat el senyoriu d'Aiora sencer (Enciclopedia.cat s.v. Gandia, ducat de); però aquest era una peça ben grossa que va anar a parar als Trastàmares, que el van atorgar com a recompensa a membres de la noblesa castellana del seu bàndol.

${ }^{20}$ García-Oliver et al. 2009-2010, pp. 11-12.

${ }^{21}$ Cantavella 2012.

${ }^{22}$ Amorós 1960, p. 458.

${ }^{23}$ Ibidem. 
mort de l'abadessa, a falta d'exhumar més documentació haurem de suposar que aquesta hauria mort a la primera meitat dels anys trenta. De quan va morir la seua germana Elionor no en tenim notícia.

També cal esmentar dos oncles més, fills il·legítims d'Alfons el Jove, que no va tenir descendència legítima, i dels quals se sap poc. Aquests no van ser tractats per Alfons el Vell amb la consideració dels altres néts legítims i il·legítims ${ }^{24}$. Donada la distància que mantenia el Jove respecte de la resta de la família, és difícil saber si els seus fills es van relacionar en termes familiars amb la filla d'Enric.

Tornant a l'oncle carnal d'Isabel, cal dir que Galvany de Villena va ser un noble interessat a mantenir l'autonomia del seu orde contra el que veia com a ocasionals abusos de la corona, com mostra el fet que en diverses ocasions pren el bàndol del seu cosí Hug de Cardona per aquest motiu ${ }^{25}$. Galvany, que rep el tractament de "molt noble mossèn Galvany de Villena" ${ }^{26}$, va contribuir econòmicament al nou edifici del monestir de la Trinitat, l'edifici del convent impulsat per la reina Maria on es va traslladar aquella comunitat clarissa de Gandia, i on la seua neboda va ser la primera novícia, amb la xifra més alta possible: 55 lliures consten en el llibre d'almoines del convent, xifra a què ben pocs altres nobles valencians van $\operatorname{arribar}^{27}$.

Malgrat la seua condició d'il·legítim, Galvany de Villena va fer un molt bon casament: va contraure noces en 1403 - poc després d'haver rebut la donació del seu avi -amb Violant de Vilaragut ${ }^{28}$, germana d'aquell Joan de Vilaragut amb qui la reina viuda Margarida de Prades es va casar en secret, i que era així mateix il·legítim ${ }^{29}$. Martí de Riquer esmenta Galvany de Villena en 1418 , com a missatger portador d'una lletra de batalla del seu cunyat Joan de Vilaragut contra Pero Maça ${ }^{30}$. I el nom de Galvany de Villena torna a aparèixer associat al de Pero Maça en un document de 1437, en què ambdós,

${ }^{24}$ Castillo 1999, pp. 130-131 i notes 308 a 310.

${ }^{25}$ López 2005, pp. 321-323.

${ }^{26}$ Vegeu per exemple Català, Pérez 2002, p. 85.

${ }^{27}$ Mata 1991, entrada 336.

${ }^{28}$ Castillo 1999, p. 126, qui registra en la nota 296 les moltes despeses relacionades amb el casament, que sufraga l'avi Alfons: "es tracta pràcticament d'un aixovar".

${ }^{29}$ Fort i Cogul 1970; Zaforteza 1970.

${ }^{30}$ Riquer 1984, pp. 68-69. "Que Joan de Vilaragut i Galvany de Villena fossin cunyats explica que aquell encomanés a aquest la recepció de les lletres que li adreçarà don Pero Maça, car ja veurem que existien poderoses raons que impedien que les trametés directament al palau". "L'herald Catalunya, oficial d'armes que consta al servei del rei fins al 1433, havia estat encarregat de portar la lletra de Joan de Vilaragut a don Pero Maça; i aquest li'n remeté resposta, dos dies després, al domicili de Galvany de Villena, per mitjà de l'herald València" (ibidem, p. 69). 
amb Hug de Cardona i Joan de Próixita, són denominats "milites, consiliarii dictorum dominorum regem" ${ }^{31}$.

Galvany i Violant van tenir una filla, Caterina de Villena, única hereua de senyorius i béns. Sembla que aquesta hauria pogut tenir un germà legítim, de nom Pere de Villena; però aquest no apareix esmentat en el testament de l'àvia Teresa Álvarez de Haro, sogra de Galvany, en 1420: fa pensar que ja devia ser mort ${ }^{32}$. Galvany, per la seua banda, va morir el març de $1447^{33}$. A la seua mort, Elionor tenia uns disset anys i tot just feia un any que havia professat a la Trinitat; com es veu, Galvany va ser l'únic oncle carnal que va conèixer ella: la tia Elionor, mare dels cosins italians, hauria mort almenys vint-i-sis abans; l'oncle Alfons en duia mort més de quaranta-cinc.

Sembla que Violant de Vilaragut només va sobreviure a Galvany un any, i hauria mort en $1448^{34}$. Tanmateix, al llibre d'almoines de la Trinitat, Galvany es dóna com a viu mentre que Violant apareix com a quondam, ja difunta. Aquesta divergència es pot conciliar si considerem que el llibre d'almoines de la Trinitat s'hagué d'estar escrivint al llarg d'anys, cosa natural. Això explicaria que marit i muller no figuren en la mateixa pàgina, sinó molt distants: Galvany hi és a l'entrada 336, i la ja quondam Violant, a la 2053. Encara molt més avant, a l'entrada 2580, consta la contribució de la egrègia dona Cathalina de Villena (observeu-ne el tractament), sense indicació de la quantitat donada ${ }^{35}$. Hi figura així per la contribució del seu testament? (Vegeu nota 40).

El matrimoni es va fer soterrar no a la Trinitat, sinó al convent de predicadors de València, del qual aquesta família va ser important benefactora. S'hi van fer construir una sepultura important, de la qual sembla que prové el fragment de llosa treballada (mènsula i clau) que inventarià Caruana, ja que correspon fil per randa a l'antiga descripció de la sepultura de Galvany i Violant reportada per Teixidor ${ }^{36}$, i donat també que Caruana en considera el convent de predicadors de València com a provinença més probable ${ }^{37}$.

${ }^{31}$ Els quatre apareixen signant com a testimonis de la confirmació de Joan de Navarra, lloctinent general del regne, a una sentència emesa per Joan Mercader i Joan Gascó (García-Oliver et al. 2009-2010, vol. I, p. 697, doc. 149).

${ }^{32}$ Zaforteza 1970, pp. 530-532. "Tenía una nieta legítima, doña Catalina de Villena y de Vilaragut (...) y además un nieto legítimo, hermano de la anterior, don Pedro de Villena, a quienes llamaba hijos; mas hay que tener en cuenta que igualmente legítimo era Juan Jerónimo y éste es el elegido, y en último término doña Catalina, pero nunca don Pedro" (ibidem p. 532). Caterina, ens hi diu Zaforteza, pledejaria amb el seu cosí Joan Jeroni (el fill de Margarida de Prades i Joan de Vilaragut) per la seua part de l'herència familiar.

${ }^{33}$ Teixidor 1949-1952, p. 31.

${ }^{34}$ Ibidem, pp. 29 i 31.

${ }^{35}$ Mata 1991, entrades 336, 2053 i 2580.

${ }^{36}$ Teixidor1949-1952, p. 29.

${ }^{37}$ Caruana 1926, pp. 11-12. 
Caterina de Villena continuà afavorint el convent de predicadors, com havien fet els pares, $i$ hi va ser soterrada en la sepultura familiar ${ }^{38}$. A la seua mort sense descendència el 1475, va llegar les seues propietats a diferents parents. Els principals hereus, ja difunts ${ }^{39}$, n'eren Pere i Alfons de Cardona i de Villena, cosins germans de Caterina i d'Isabel, per ser fills de l'Elionor de Villena que s'havia casat amb Antoni de Cardona. Per l'època que Isabel de Villena (a qui portaven uns vint anys) va nàixer, vivien ja amb el pare a Sicília i Nàpols, on prosperarien molt al costat del Magnànim, però lluny de la cosina germana ${ }^{40}$.

Caterina, en el seu testament, també esmentava la deixa feta a Isabel de Villena:

abbadessa del dit monestir de la Sancta Trinitat, cara cosina germana nostra, tots los molins constituhits dins la nostra vall de Cortes per supplir algunes misèries e necessitats de aquella, durant la vida de aquella tan solament ${ }^{41}$.

Caldrà aclarir el possible dubte: podia haver estat Galvany de Villena el pare d'Isabel? La resposta és que no hi ha base per a considerar-ho. Per exemple, si Galvany ho hagués estat, per què fer-se soterrar al convent dels dominics i no a la Trinitat, monestir de la que hauria estat la seua filla? D'altra banda, és inequívoca la fórmula cara cosina germana que empra Caterina de Villena per referir-se a l'abadessa: no hi ha testimonis lèxics de dir-se cosins germans els qui siguen germanastres. I encara: hauria rebut a l'edat mitjana tanta consideració social, tant de respecte, una bastarda filla de bastard?

Tot i descartar, doncs, la paternitat de Galvany de Villena, aquesta és una figura que hem de seguir considerant en relació a Elionor/Isabel. El fet que visqués a València, a la mateixa ciutat on residia la neboda, ha de determinar necessàriament la nostra consideració sobre les circumstàncies familiars de la nena i jove Elionor: aquesta, a més de tenir o haver tingut a prop les ties àvies clarisses, mentre va crèixer a la cort de la reina Maria comptava amb un oncle veí en qui recolzar-se en cas de necessitat; un recolzament que es manifesta en la generosa

\footnotetext{
${ }^{38}$ Teixidor 1949-1952, pp. 31-32.

${ }^{39}$ Català, Pérez 2002, p. 40.

${ }^{40}$ Vegeu Enciclopèdia.cat, s.v. Cardona i de Villena, Pere i Cardona i de Villena, Alfons.

${ }^{41}$ Català, Pérez 2002, pp. 39 i 96. No costa suposar que aquestes "algunes misèries e necessitats" atribuïdes a l'abadessa tingueren relació amb les contínues obres del monestir, que ella dirigia, i que es van perllongar fins a la seua mort i encara més enllà (vegeu Benito 1998 i Cantavella 2011). No es necessari atribuir a "misèries e necessitats" connotacions de gran pobresa; vegeu per exemple aquest extracte: "Mercader hi al·lega una donació d'Alfons el Jove per 'haver sostenguts - deia el duc - diverses affanys e treballs en temps passat en nostres extremes necessitats, axí en patrocini e advocació com àls"' (Garcia-Oliver et al.2009-2010, vol. I, p. 35 i doc. 104 r. 5-6). Els deutes d'Alfons el Jove solien ser pel joc.
} 
aportació econòmica del molt noble mossèn Galvany al convent de la neboda. I a la mort de Galvany poc després de professada Isabel al convent, la relació amb la família d'aquest continua, com ho mostra l'afecte amb què Caterina de Villena es refereix, en el testament suara citat, a la seua cara cosina germana.

Tot això ens obliga a abandonar la impressió d'aquesta autora com a orfeneta desvalguda vivint, sense família directa, de la caritat de la reina. Elionor tenia en Galvany un oncle carnal que podia protegir-la i donar-li suport; algú que comanava respecte i que havia esdevingut un dels grans barons del regne de València; un oncle amb qui compartia, a més, l'experiència de la illegitimitat. Hem vist, igualment, que Isabel de Villena tenia també en València una cosina germana amb qui mantingué, per les traces, una relació afectuosa. I a això hem de sumar: les ties àvies monges a la Puritat -que la van haver de conèixer en la seua primera infantesa-, els seus cosins germans a Itàlia, i les seues altres ties segones: Elionor de Prades i la desconeguda Violant, monja clarissa i segona abadessa de la família abans de l'escriptora. Així s'entén plenament l'opció d'Isabel de Villena pel franciscanisme: amb almenys tres parentes clarisses, en professar a la Trinitat, la futura escriptora continuava una tradició familiar, i alhora feia perviure -amb una importantíssima aportació econòmica, com després veurem- el projecte de comunitat clarissa de la tia àvia Violant.

\section{MOTIUS PER A L'ADSCRIPCIÓ D’ISABEL A LA CORT}

Amb tota aquesta parentela al voltant, cal replantejar-se per què la nena Elionor de Villena va ser criada a la cort, i no amb algun dels seus molts familiars. Podia haver crescut en casa de l'oncle Galvany; amb els cosins germans Cardona a Itàlia; amb la tia Elionor de Prades; fins podia haver-se criat al convent amb les ties àvies. Per què amb la reina Maria, doncs, i no amb parents?

La pregunta encara es fa més necessària si tenim present que les circumstàncies polítiques havien acabat convertint l'únic nét baró legítim d'Alfons el Vell en enemic dels Trastàmares, com veurem. Hem de renunciar a la suposició que la reina Maria hagués replegat en la seua cort l'òrfena d'Enric de Villena simplement per afecte. Ara sabem que Alfons i Joan de Trastàmara van actuar abusivament amb qui havia estat persona de confiança del seu pare el rei Ferran.

El motiu pel qual Enric, que tenia tants vincles amb el regne de València, va passar els últims anys de la seua vida a Iniesta, ha de tenir relació amb el fet que els germans Trastàmara el van exiliar. Jaume Castillo ens fa el resum de l'operació:

L'any 1422, assabentat de la malaltia del seu oncle, Alfons el Jove, [Enric] mirà d'aproximar-se a la cort gandiana amb l'objectiu de ser almenys candidat a rebre en herència el ducat. Les actuacions 
judicials de Joan de Navarra, aleshores ja agraciat amb el ducat de Gandia davant la perspectiva d'una propera mort del seu titular sense hereus, i del governador mateix Vidal de Blanes, foren fulminants, tot i que els representants de la vila de Gandia i Alfons el Jove mateix no veien amb mals ulls la presència d'Enric. La resolució fou molt contundent i Enric fou expulsat per ordre del governador, no només del ducat de Gandia, sinó del regne de València; i això que el seu delicte es limitava a "atemptar" contra els drets de Joan de Navarra, garantits per carta reial des d'octubre de $1417^{42}$

Que Alfons i Joan Trastàmara, operant de manera conjunta, forçassen Enric a l'exili per una iniciativa abocada al fracàs als tribunals però perfectament legal, resulta molt significatiu. Enric de Villena, vist des de la posteritat com a autor tolerable des del punt de vista literari, però des del polític com a personatge risible, havia estat pres molt seriosament pels Trastàmares com a enemic, és a dir, com a rival ${ }^{43}$. És difícil concebre l'impacte que això degué tenir en Enric: exiliat com un vulgar traïdor pels fills de Ferran d'Antequera, el rei nouvingut amb qui ell tant havia col-laborat; el rei foraster a qui ell va ajudar a arrelar socialment, per exemple recomanant-li el patrocini dels certàmens poètics que tant apareixien associats als reis de la dinastia anterior, i representant-lo com a ambaixador davant el $\mathrm{Papa}^{44}$. I malgrat aquest tracte, pocs

\footnotetext{
${ }^{42}$ Castillo 1999, p. 125, qui afegeix en nota 288: "I qui sap si [els gandiencs] contemplaven la possibilitat que Enric de Villena, veritable successor d'Alfons el Vell, ja aleshores convertit en un mena d'heroi i un idealitzat «bon senyor» d'altres temps, fóra el pròxim duc de Gandia. Segurament el preferien a un estrany com Joan de Navarra. De fet els representants de la vila protestaren de manera contundent les accions del governador, absolutament atípiques per la seua arbitrarietat i celeritat" (ARV, G 2.228, mà 14, f. 45r, mà 20, ff. $15 \mathrm{r}-17 \mathrm{v})$.

43 "És cert que tant el segon duc de Gandia com el seu nebot Enric hagueren d'enfrontar-se amb l'home més astut i ambiciós de tota la parentela: l'infant Joan de Trastàmara (...). Les seues intervencions en els darrers anys de la vida del segon i darrer duc de Gandia de la nissaga d'Aragó a Gandia, foren inacceptables en tots els sentits, però comptaren amb el recer atorgat per Margarida de Prades, reina viuda del rei Martí, el comte de Cardona i el vescomte de Vilamur (...). Enric d'Aragó i de Castella, dit de Villena, foragitat de Gandia i València, se n'anà a Castella, on li concediren el senyoriu d'Iniesta -ara dins l'actual província de Conca- per tal que tinguera unes rendes de per vida" (Orts 2011, p. 8).

44 "Tant agradaren al sobirà [els entremesos a Ferran I], que diuen que inflürren en els de les festes de la seva coronació a Saragossa l'any 1414, dirigits i compostos per Don Enric de Villena"; "[Enric de Villena] Vivió más en tiempos de Alfonso el Magnánimo que bajo don Fernando, pero fue por su protección que sintió por vez primera, que sepamos, el halago del éxito de público al intervenir en las fiestas barcelonesas de la Gaia Ciència. Villena es la síntesis de algunos fenómenos literarios del Renacimiento, tanto en la literatura castellana como en la catalana, pero no sé por qué se le estudia como una personalidad aislada en su erudición y como trabajando en cierta incomunicación con el tono del país. Creo que sería iluminadora toda tentativa para romper el cerco. Hoy sabemos que marchó a Aviñón con el barcelonés Felip de Malla en 1415, enviado por el rey a entrevistarse con el emperador sobre la cuestión del Cisma. $\mathrm{Ni}$ el ambiente de aquella ciudad, ni la gente que allí conoció, ni su compañero de viaje podían
} 
anys després Joan encara escriu a Enric, demanant-li que li faça una traducció de l'Eneida. No és rar que, en la carta d'enviament que serveix d'exordi a l'obra, Enric de Villena diga que es posa a la feina sense gaires ganes ${ }^{45}$.

Enric intentarà reclamar per via legal l'any 1429, de nou infructuosament, els seus drets successoris als senyorius de l'avi i de l'oncle. Ho fa a un mes d'iniciada a Castella la guerra entre la facció d'Álvaro de Luna i la dels Trastàmares, els "infantes de Aragón" ${ }^{46}$. Es tracta de la guerra que va ajudar a sufragar, com ja havíem vist, el germanastre d'Enric, Galvany (vegeu notes 14 a 16). Pedro Cátedra veu així els fets de 1429:

\begin{abstract}
Alfonso de Aragón [el Jove], Duque de Gandía y tío de Villena, había muerto sin hijos en 1425. El nuestro [Enric de Villena] tenía todos los derechos para heredar los varios títulos que habían pertenecido a su abuelo. Venía reclamando el ducado de Gandía, los condados de Ribagorza y Denia, entre otras villas y tierras. El Magnánimo le viene dando largas; Juan II de Navarra sostiene que el difunto le había nombrado su heredero. La nueva guerra con Castilla viene bien al aragonés [el Magnànim] $\mathrm{y}$, según documento fechado el día 1 de abril de 1429 , por la ayuda que don Enrique había prestado a su rey [de Castella], ocupa y expropia todas las posesiones de la casa de Gandía, para, simultáneamente, donarlas a su hermano Juan II de Navarra, quien desde entonces las vincula a su patrimonio. La expropiación tiene, pues, lugar en esa fecha, pero seguramente los bienes habían sido tenidos en administración desde tiempo antes ${ }^{47}$.
\end{abstract}

Per què torna Enric a la càrrega en 1429? Simplement perquè pensa que, amb la nova confrontació bèl·lica, els Trastàmares es debilitaran políticament? O és també que se sap ja futur pare, i vol intentar-ho pel bé del seu hereu?

Donat aquest historial de tractament hostil a Enric per part dels Trastàmares, no sembla que l'afecte familiar fos motivació suficient per al gest de la reina, en fer-se càrrec de l'òrfena d'Enric. Certament Maria de Castella i Elionor de Villena eren parentes, però no directes. Com he indicat, l'àvia

ser indiferentes a don Enrique. Una exploración en este sentido podría decirnos muchas cosas" (Rubió 1990, pp. 147 i 165).

${ }^{45}$ Enric diu que comença aquesta traducció el vint-i-vuit de setembre de 1427. En el resum de Pedro Cátedra (1994, vol. II, p. xvi): "Dice, por ejemplo, que accede a ponerse al trabajo a pesar de lo muy ocupado que estaba y del esfuerzo que requería la traducción (...). No obstante, se va a poner manos a la obra porque, entre otras cosas, así podrá demostrar al sobrino la buena disposición que le tiene, a pesar de la poca humanidad con la que le está tratando por entonces".

${ }^{46}$ Ho indica Pastor 1992, p. 136 i n. 20 (on remet a AHN, Osuna, llig. 1.391, 9, núm. 1 (1-IV-1429)).

${ }^{47}$ Cátedra 1994, vol. II, p. XVIII). 
paterna de l'escriptora, Joana de Castella, era filla il·legítima d'Enric II de Castella, també besavi de Maria: Elionor i Maria eren cosines primes. Tenien també un altre parentiu més tènue: l'àvia de Maria, Elionor d'Aragó, era néta de Jaume II, ascendent en cinquena generació de l'escriptora: per aquesta via eren igualment cosines, però encara més primes ${ }^{48}$.

Cal també descartar la caritat com a motivació de la reina en criar Elionor a la seua cort: la donzella Elionor de Villena posseïa una molt significativa renda de la seua propietat a Salamanca. Sembla, més aviat, que la "caritat" va anar en l'altra direcció: segons indica el llibre d'almoines per a les obres del convent de la Trinitat, Elionor havia fet prèvia donació a la reina (quan? per quina "certa causa"?) d'aquestes rendes, que ascendien a vint mil morabatins:

E mes avant, considerant la dita senyora [reina] que una neboda sua apellada tunch dona Elionor de Villena, donzella de la sua cort, novament s'era donada al servir de Déu en lo dit monestir, prenent l'àbit e vida de aquell, la qual havia fet donació de vint mília morabatins de jure de heredat, los quals la dita donzella possehia en la ciutat de Salamanca, a la dita senyora per certa causa, la dita senyora, en satisfactio del dit donatiu, e per esguart de la dita obra, e neboda sua, donà en diverses partides al dit monestir, segons lo dit receptor [Pere Sancho] féu rebuda de aquells al dit tresorer [el notari Guillem Bernat Çaburgada], dos mília e quatrecents florins d'or, qui valien tunch de la dita moneda corrent, a rahó de xii lliures [llegiu-hi 'sous'], vint e huit mília huit-cents sous $^{49}$.

Aquesta magnànima aportació reial a les obres de la Trinitat, va ser feta en realitat, doncs, amb diners de la filla d'Enric de Villena. De fet, en el mateix llibre d'almoines, on es recullen les aportacions realitzades per a la renovació del monestir de la Trinitat, es consigna que totes les monges i noves professants fan la més alta aportació possible: 55 lliures. Isabel no n'és excepció. Allà es mostra que la besnéta d'Alfons el Vell va estar a l'alçada de les circumstàncies, igualada en aportació econòmica per pocs nobles valencians. Aquestes 55 lliures se sumen, doncs, als 28.800 sous de la seua propietat donats per via reial al convent. Si una lliura eren vint sous, les 55 lliures suposaven 1.100 sous a afegir als 28.800 sous de l'esmentada donació. En total, doncs, Isabel de Villena va aportar al convent 29.900 sous, i això sense comptar-hi el seu dot, que no sabem a quant ascendiria. Per fer-nos idea

\footnotetext{
${ }^{48}$ Orts (2011, p. 10) explicita l'ascendència d'Isabel de Villena, així com el parentiu entre les dues (ibidem p. 8).

${ }^{49}$ Mata 1991, p. 9.
} 
de la proporció, cal recordar que la tia àvia havia proveït per a la fundació del convent de Gandia amb 3.000 sous: un simple 10\% de la donació de la neboda; i que, després de morta Violant, les seues hereues havien estat en plets durant molts anys per les quantitats de, respectivament, dos mil i mil sous. En el cas d'Isabel de Villena parlem, doncs, d'una fortuna molt considerable, que (sumada, naturalment, a aportacions diverses de la societat, però que rarament arribaven a les 55 lliures) va contribuir a fer del convent hereu del de Gandia una de les joies del gòtic valencià del segle XV.

Elionor de Villena havia posseït, doncs, una renda molt respectable a Salamanca. D'on li venia? De son pare, com a romanent dels senyorius i honors castellans que havia ostentat? Era herència per via de l'àvia Joana de Castella, filla natural d'Enric II i esposa de Pere de Villena? És difícil imaginar que li vingueren per via materna, però i si fos així? El que resulta poc probable és que, si aquesta font de riquesa venia de la banda paterna com és ben probable, Enric la rebés del duc Alfons el Jove, oncle seu: un document de 1422, referent al plet entre Pere de Luna i Bernat de Vilarig per l'herència de la baronia d'Arenós, indica que el duc (famós per la mala relació amb els seus parents) ha preferit deixar-la a Vilarig, que no li és família, i desheretar així tant les seues germanes com sos nebots, axí com és lo egregi don Anrich, nebot seu, fill del egregi don Pedro de Villena, quondam, frare del dit egregi duch vivent ${ }^{50}$. L'egregi Enric de Villena, doncs (noteu, de nou, l'elevat tractament que rep la família), no hauria heretat res per aquesta via, a no ser que l'idiosincràtic oncle hagués canviat d'opinió en l'últim moment. Per descomptat, una altra possibilitat seria que Enric hagués guanyat aquesta fortuna d'alguna manera. Escrivint? Resulta difícil de creure, per desgràcia; però cal plantejar-se totes les possibilitats. Algun dia ho sabrem.

El cas és que aquesta seua fortuna, doncs, ens obliga a oblidar també la impressió d'una Elionor de Villena com a parenta pobra, replegada a la cort per compassió.

En canvi, cal plantejar-nos una factor alternatiu, motiu clau per explicar la voluntat reial de fer criar la filla d'Enric de Villena a prop de la reina Maria. Es tracta d'una consideració de màxima importància des del punt de vista polític: Elionor, per més il-legítima que fos, era filla reconeguda de l'únic nét per via legítima masculina del duc Alfons el Vell, un dels aspirants al tron d'Aragó a la mort de Martí l'Humà. I els Trastàmares, com ha provat documentalment María Narbona en una publicació recent, havien mamprès una astuta política de tutelatge de les donzelles descendents dels que havien

${ }^{50}$ García-Oliver et al. 2009-2010, vol. II, p. 66, doc. 8. 
estat altres aspirants al tron durant l'interregne ${ }^{51}$. Per què no havien de fer el mateix amb Elionor? El rei Ferran ja s'havia ocupat de fer venir a la cort, per ser educades sota la seua vigilància, Isabel i Elionor, les filles grans del comte d'Urgell (per a horror de l'àvia d'aquestes, la comtessa viuda), i les va casar al seu gust. Alfons el Magnànim va seguir executant aquesta política, concentrant entorn de la reina Maria, i sota el seu ull vigilant, una sèrie de donzelles: Violant d'Aragó, filla il·legítima de Martí el Jove, va pertànyer a la casa de la reina fins al seu matrimoni; Caterina i Joana, filles més joves del comte d'Urgell, rere la mort de sa mare també van ser portades a la cort de la reina Maria, com ho havien estat les més grans a la cort de la reina Elionor. Caterina va morir poc després; no s'hi va adaptar. Joana sobreviu, i rep el tracte d'infanta, amb seguici propi. Joana va casar primer amb el comte de Foix, i en enviudar, amb el comte de Cardona, conseller reial ${ }^{52}$. Vista aquesta sistemàtica línia política, era ben lògic que la filla de l'únic nét legítim d'Alfons el Vell rebés el mateix tracte, barreja de consideració i de vigilància. Totes, excepte Elionor, es casen: realitzen casaments polítics per a benefici dels Trastàmares. És evident que ni Alfons el Magnànim ni el seu germà Joan no podien voler que aquestes donzelles de sang reial es casassen amb ningú que pogués, passat el temps, reivindicar drets successoris per als seus fills per una ascendència que els connectària a l'antiga dinastia d'Aragó ${ }^{53}$. No pot estranyar que els Trastàmares es proposassen extingir completament el llinatge reial de la casa de Barcelona.

Que existissen tots els condicionants indicats en l'ingrés de la nena Elionor de Villena a la cort de la reina Maria, no significa que no hagués pogut crèixer un afecte entre les dues ${ }^{54}$. És, simplement, que aquest apropament va obeir primer que res al projecte polític suara vist.

A la llum de totes les notícies considerades, que ens ajuden a entendre la circumstància familiar i vital d'Isabel de Villena, resulta natural que els coetanis d'Isabel de Villena tinguessen presents tant la seua genealogia reial com les circumstàncies polítiques relatades, i que la lloaren com a descendent de reis -dels reis de la casa de Barcelona, a més; d'aquells que havien viscut en els regnes que administraven. Ara podem llegir amb més gran coneixement de causa les lloances a la seua nissaga efectuades pels seus admiradors:

\footnotetext{
${ }^{51}$ Narbona 2009.

${ }^{52}$ Ibidem, pp. 111-113.

53 "Quiso el rey asegurarse de que las hijas del conde casasen a gusto suyo, por escusar los inconvenientes que podían seguirse casando fuera de estos reinos a disgusto suyo", document de CODOIN (vol. II, pp. 595-596) citat per Narbona 2009, p. 112, n. 75.

${ }^{54}$ Orts $(2011$, p. 8) presenta una hipòtesi no improbable: 'La reina Maria havia nascut l'any $1401 \mathrm{i}$, per tant, tenia vint-i-nou anys més que la seua cosina, la qual certament vingué a omplir el buit de la manca de fills per part de la reina i l'absència continuada del marit".
} 
D'aquella tan alta, tan fort y gran çoca / del arbre real dels reys d'Aragó, / sou vós una branca ab virtut no poca (Bernat Fenollar). A vós, la pastora tan digna d'aquelles / que tant conversau humilment ab elles, / vestint rica porpra de tan real sanch (Pere Martines) ${ }^{55}$ Essent gran senyora, e de real linatge, haveu menyspreat de aquest trist món les honors e riquees" (Miquel Péreç) ${ }^{56}$. "Regia ex yspanorum et illustri propagine nobilissime filie (Jaume Péreç) ${ }^{57}$.

Ens ha de resultar palesament clar, tal com ho resultava a la València del segle $X V$, que a més de per la seua gran vàlua personal ${ }^{58}$, el prestigi d'Isabel de Villena li ve incontestablement de la seua família directa, i no tant de la proximitat a Maria de Castella. Els seus coetanis, vivint en una època de ràpid canvi polític i de galopant concentració de poder a Europa, en mostrarli respecte també mostraven respecte -i probablement recança- per l'antiga dinastia perduda: la de les quatre barres; aquella que no hauria tingut més prioritat que Aragó.

\section{BIBLIOGRAFIA CITADA}

AA.DD. (1655), Cenotafio funeral del doctor Melchor de Villena, València, Geronimo Villagrassa.

Amorós, León (1960), El monasterio de Santa Clara de Gandía y la familia ducal de los Borja, "Archivo Ibero-Americano" 20, pp. 441-486.

Benito Goerlich, Daniel (1998), El Real Monasterio de la Santísima Trinidad, València, Consell Valencià de Cultura.

Bofarull, Manuel de (1869), Guerra entre Castilla, Aragón y Navarra: compromiso para terminarla, año 1431, "Colección de Documentos Inéditos del Archivo de la Corona de Aragón” 37, pp. 1-489.

Cantavella, Rosanna (2011), Intellectual, Contemplative, Administrator: Isabel de Villena and the Vindication of Women, dins Hazbun, Geraldine; Ros, Xon de (eds.) A Companion to Spanish Women's Studies, Londres, Tamesis, pp. 97-107.

\footnotetext{
${ }^{55}$ García Sempere 2002, p. 225 vv. 6-8, i p. 229 vv. 59-61.

${ }^{56}$ Dedicatoria del seu Gerson: De menyspreu del món [traducció de Thomas a Kempis Imitatio Chisti], València, 1491.

${ }^{57}$ Introducció al seu Canticum Virginis, comentari sobre el salm Magnificat, dins la seua Expositio super Cantica Evangelica, València, 1485, f. 104r.

${ }^{58} \mathrm{D}$ 'aquesta no hi ha dubte, per la gran activitat i l'obra de l'abadessa com per variats testimonis coetanis. En remarcaré el del canonge Jaume d'Eixarc, que, contravenint la prohibició dels Furs, la va fer marmessora del seu testament malgrat ser dona, justificant-ho d'aquesta manera: "a la reverent madona Ysabel de Villena, abadessa de la Sancta Trinitat fora los murs de València, encara que no fos abadessa, car en açò no contemple la dignitat, sinó la sua indústria e gran confiança" (Cortés, Pons 1993, p. 184).
} 
Cantavella, Rosanna (ed.) (2012), Alfons el Vell Lletra a sa filla Joana, de càstig e de bons nodriments, Gandia, CEIC Alfons el Vell.

Caruana y Reig, José (1926), Litología blasonada, València, Tip. Moderna.

Castillo Sainz, Jaume (1999), Alfons el Vell, duc reial de Gandia, Gandia, CEIC Alfons el Vell.

Catalá Sanz, Jorge; Pérez García, Pablo (2002), Los moriscos de Cortes y los Pallás: documentos para su estudio, València, Universitat de València.

Cátedra, Pedro M. (1981), Para la biografía de Enrique de Villena, "Estudi General" 1-2, pp. 29-33.

Cátedra, Pedro M. (1983), Enrique de Villena y algunos humanistas, dins García de la Concha, Víctor (ed.), Nebrija y la introducción del Renacimiento en España, Salamanca, Universidad de Salamanca, pp. 187-203.

Cátedra, Pedro M. (ed.) (1994), Enrique de Villena Obras completas, 3 vols., Madrid, Turner Libros.

Cátedra, Pedro M.; Carr, Derek (eds.) (2001), Epistolario de Enrique de Ville$n a$, Londres, University of London.

Cortés, Josepa, i Pons, Vicent (1993), La biblioteca jurídica de Jaume d'Eixarc, "Saitabi" 43, pp. 181-194.

Cotarelo y Mori, Emilio (1896), Don Enrique de Villena: su vida y obras, Madrid, Est. Tipográfico Sucesores de Rivadeneyra.

Courcelles, Dominique de (2000), En Mémoire d'elle et en mémoire du sang: la Vita Christi de Sor Isabel de Villena, abbesse des clarisses de Valence au XVe siècle, "Le Journal de la Renaissance" 1, pp. 103-120.

Fort i Cogul, Eufemià (1970), La llegenda sobre Margarida de Prades, Barcelona, Fundació Salvador Vives Casajuana.

García Sempere, Marinela (ed.) (2002), Lo Passi en cobles (1493): estudi $i$ edició, Alacant, Institut Interuniversitari de Filologia Valenciana Barcelona, Publicacions de l'Abadia de Montserrat.

García-Oliver, Ferran; Aparisi, Frederic; Rangel, Noelia; Royo, Vicent (eds.) (2009-2010), Hug de Cardona: col-lecció diplomàtica (1407-1482), 2 vols, València, Universitat de València.

López, Atanasio (1943), El franciscanismo en España durante los pontificados de Calixto II, Pío II y Paulo II a la luz de los documentos vaticanos, "Archivo Ibero-Americano" 3, pp. 496-570.

López Rodríguez, Carlos (1991), El brazo militar del reino de Valencia a comienzos del siglo XV, "Hidalguía" 226-227, pp. 616-640.

López Rodríguez, Carlos (2005), Nobleza y poder político en el Reino de Valencia (1416-1446), València, Universitat de València.

Mata López, Manuel (ed.) (1991), Relación de limosnas para la construcción del Monasterio de la Trinidad de Valencia, Saragossa, Anubar. 
Narbona Cárceles, María (2009), Noblas donas: las mujeres nobles en la casa de María de Castilla, reina de Aragón, "Studium Revista de Humanidades" 15, pp. 89-113.

Orts i Bosch, Pere Maria (2011), Isabel de Villena (Elionor d'Aragó i de Castella), dins Escartí, Vicent Josep (ed.), Isabel de Villena Vita Christi, València, Alfons el Magnànim, pp. 7-13.

Pastor Zapata, José Luis (1992), Gandia en la Baixa Edat Mitjana: la vila i el senyoriu dels Borja, Gandia, CEIC Alfons el Vell, 1992.

Péreç, Jaume (1485), Expositio super cantica evangelica, València, Alphonsus Fernandez de Corduba.

Péreç, Miquel (1491), Gerson: De menyspreu del món [traducció de Thomas à Kempis Imitatio Christi], València, Pere Hagenbach e Leonard Hutz.

Riquer, Martí de (1984), Vida i aventures de don Pero Maça, Barcelona, Quaderns Crema.

Rubió i Balaguer, Jordi (1990), Humanisme i Renaixement (Obres de J. Rubió $i$ Balaguer, vol. VIII), Barcelona, Departament de Cultura de la Generalitat de Catalunya - Publicacions de l'Abadia de Montserrat.

Tate, Robert Brian (ed.) (1965), Fernán Pérez de Guzmán, Generaciones y semblanzas, Londres, Támesis.

Teixidor, José (1949-52), Capillas y sepulturas del Real Convento de Predicadores de Valencia, 3 vols., València, Acción Bibliográfica Valenciana.

Zaforteza Musoles, Diego (1970), Segundas nupcias y viudez de una reina aragonesa (1409-1451), dins IV Congreso de historia de la Corona de Aragó, Mallorca 1955: actas y comunicaciones, Barcelona, Archivo de la Corona de Aragón, pp. 517-538.

Zurita, Jerónimo (1977), Anales de la Corona de Aragón, vol. V, Saragossa, Institución Fernando el Católico, 1977. 
Isabel de Villena i família

Arrodonits: il.legítims.

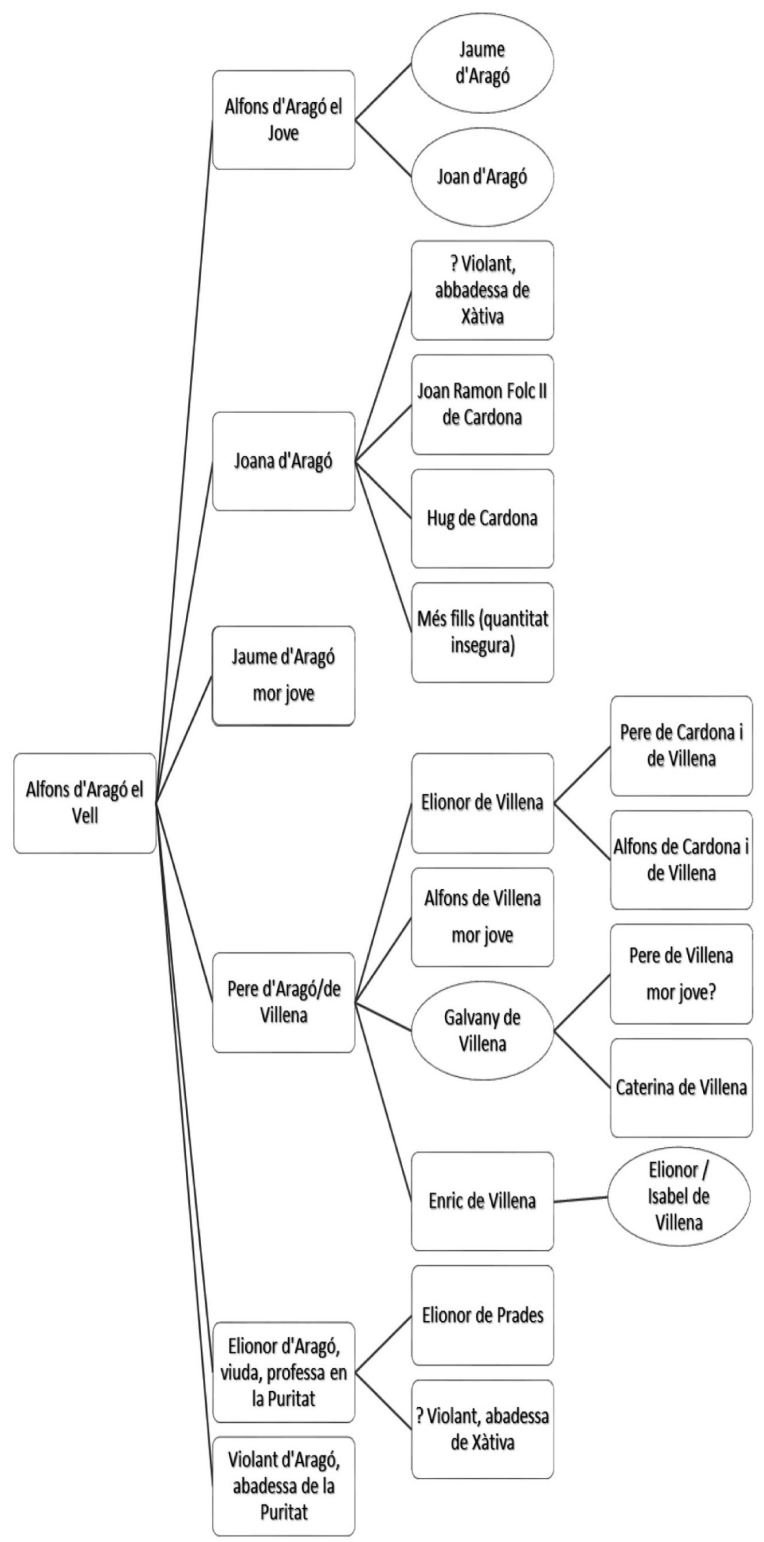

Fecha de recepción del artículo: enero 2013

Fecha de aceptación y versión final: diciembre 2013

ANUARIO De Estudios Medievales, 45/2, julio-diciembre 2015, pp. 715-732

ISSN 0066-5061, doi:10.3989/aem.2015.45.2.03 